\title{
Application of the Incentive Mechanism in the Construction of the Party Branch of University Teachers
}

\author{
Liu Ying xia \\ Dalian University College of Marxism \\ Dalian, China \\ Email: lyx111505@sina.com
}

\begin{abstract}
The Party branch of University Teachers' basic level party is the political core, which plays an important role in the rule of law. However, the enthusiasm of the teachers is not high, the role of the pioneer model is not good, and the mechanism of the incentive mechanism is not perfect. To adapt to the new period comprehensive strictly requirements, managers need to understand the work motivation of university teachers, teachers are analyzed the hierarchy of basic human needs, in under the guidance of the development orientation, improve the scientific level of management. In this article, we find that there is a positive difference between the party members and the party members in the construction of University Teachers' Party branches. The problems such as the lack of innovation of the party members' enthusiasm, the cohesion of the party, the lack of work and the form of the work, and the lack of incentive mechanism. In order to guide the construction of incentive mechanism and find the basic way to improve the development of the Party branch, the main contribution of this paper is to guide the construction of the incentive mechanism.
\end{abstract}

Keywords-Incentive; Incentive mechanism; Innovation; Party branch; University Teachers;

\section{INTRODUCTION}

Man's behavior is controlled by the motivation, the motivation is caused by the need, and the direction of people's behavior is in constant pursuit of the goal, to meet the needs of development. As an important carrier of Party building work in Colleges and universities, the Party branch must be continuously explored and innovative, and the improvement of the incentive mechanism to promote the construction of the party branches of teachers is a good way to choose.

\section{The CONNOTATION AND TYPES OF MotiVATION THEORY}

People's behavior needs to have a sustained development momentum, the source of this power is the satisfaction of material life. On the other hand, it is the spiritual needs and the realization of the individual selfvalue. Therefore, the university administrators need to formulate and implement appropriate incentive policies and measures in the spirit.

\section{A. Connotation of Motivation}

Motivation is the process of the individual's intrinsic motivation and making it move towards the goal and direction, and it is the process of the individual to achieve the work intensity, work orientation and the work will be reflected by the individual in order to achieve a certain goal. In general, the definition of the incentive will reflect the three main factors: intensity, direction and persistence. The so-called incentive intensity refers to the individual's attempt to pay much effort, which is the most attention in the study of the incentive behavior; The direction of the incentive is that the effort of the individual is consistent with the goals of the organization, and only the right direction can be beneficial to the development of the organization; The persistence of motivation is the time that individual effort can be maintained. Generally speaking, it is a kind of inspiration that the individual who is well motivated will be able to persist in doing a task until the goal is achieved: To always think about how to motivate employees to develop appropriate incentives to ensure that the direction of the efforts of the staff and the organization's development strategy.

\section{B. Categories of Motivation Theory}

At present, there are mainly three types of incentive theory: content based incentive theory, process incentive theory and behavior modification incentive theory [1].

1) Content-based Motivation Theory

Content-based incentive theory from the perspective of people's needs, the study of the causes of human behavior, the motivation of the excitation factor for the main research content [2].

Maslow's need hierarchy theory to people's needs from low to high score for physiological needs, security needs, social needs, respect for the needs, self-realization needs, and that the order is also from low to high, at the same time, there is always a level of need to play a leading role, and only the need to meet the needs of people play a leading role in the incentive.

Alderfer's ERG theory points out that human needs, including survival, the relationship between need and growth need, what level of needs to be satisfied less the more you want to meet this need, the needs of lower level the more get more satisfaction, the more people are eager to get a high level of satisfaction, and once the frustration, not to meet, will retreat to the lower levels to pursue low levels.

Herzberg's research conclusion shows that the factors that make employees feel satisfied with the work itself or the content of the work, including achievements, recognition, work itself, responsibility, promotion, growth, 
etc., is called "incentive factors"; The factors that cause the staff to feel dissatisfied with the work environment and working conditions, including the organization of policy and management, working conditions, remuneration, colleagues, and other ten aspects, is called "health care factor". Health care factors are not satisfied with the meeting, but the health factor is HERSHEY'S can only eliminate not satisfied, will not necessarily produce satisfactory. If the incentive factor is satisfied, the staff will be satisfied, but the lack of the incentive will not be satisfied.

McClelland 's achievement motivation theory research is in the people's physiological needs to meet the needs of people and the need to power, the need to belong to and achievement need. People who achieve a strong need to have a strong incentive to work in the inner, which is important to the development of the organization; The organization has the ownership of the need of more employees, the more conducive to create a harmonious atmosphere of work.

\section{2) Process Based Incentive Theory}

The study of process oriented motivation theory is the psychological process that people are motivated to take action. Its main task is to find out some of the key factors that determine the behavior of the behavior, and to find out the relationship between them, so as to predict and control the behavior of people. Forum's expectation theory: People are able to do a job and to achieve the goal, because the work and the organization's goal is to achieve the goal, which in turn helps to meet their own needs in some areas. The effect of the stimulation depends on two factors, namely, excitation force value $=$ effect $*$ expected value. The inspiration for the management is: To effectively motivate employees to work motivation, to mobilize the enthusiasm of the staff, need to deal with the relationship between hard work and performance, performance and reward, reward and meet the needs of the individual. Only when the value of the value and the value are higher, it will produce a strong incentive. Adams's theory of fairness: Employee's work enthusiasm is not only affected by the absolute return, but also by the relative compensation. When a person gets paid, not only concerned with the absolute value of their own income, but also concerned about the relative value of their own income, so the manager should strive to establish a relatively fair environment, guide employees to produce fair, establish a correct view of justice.

\section{3) Behavior Modification Incentive Theory}

How to transform and transform people's behavior, and to achieve the intended target, is the focus of behavior modification theory.

Rock's goal setting theory is concerned with how people react to the set goals [3]. A clear, challenging goal, with appropriate feedback, can make a greater improvement in the performance of individual work. Managers can improve the performance in two ways, one is to enlarge the intensity and duration of the efforts of the staff; Two is to give employees a clearer role awareness, so that their efforts to improve the performance of the work [4].

The strengthening theory of Skinner and his theory pay attention to the influence of environment on behavior. It is believed that human behavior is a response to external environmental stimuli, and when the results are favorable to their own, they will be strengthened or repeated; On the contrary, it will weaken or stop. Therefore, as long as the consequences of the behavior of the control can achieve the purpose of controlling and changing the behavior. The behavior can be changed by positive reinforcement, negative reinforcement, punishment and revocation of the four methods.

\section{PRoblems AND REASONS OF THE DEVELOPMENT OF THE PARTY BRANCH CONSTRUCTION OF UNIVERSITY TEACHERS}

In order to better understand the real situation of the development of the Party branch of university teachers, the author uses the method of interview and questionnaire survey to investigate the construction of the party branches of teachers in Colleges and Universities:

\section{A. Teacher Party Members Learning and Working Enthusiasm is Not High}

Most faculty members of political learning are passive form, some branch is easy to organize teachers in learning together may also be subject to interference by, such as a mission to answer the students, teaching document traversing, school work deployment, venue are often disturbed, which affected the enthusiasm of Party members to participate in the activities of, in the long run will be diluted to make consciousness of Party members ${ }^{[5]}$. Branch secretary to carry out the work of the lack of policy support, and the treatment of ordinary teachers, status is the same, "Do work, by dedication". Because there is no relevant policies and measures, the branch secretary of the task is difficult to implement, supervise and urge the assessment is difficult, more difficult work ideas.

\section{B. Branch Cohesion is Low}

This problem is highlighted in the life branch organization slack, lack of mass appeal. Due to the branch of the organization's activities often by Party members and teachers in class time constraints and the teachers' personal learning initiative is not strong, will often make branch in lax condition. Most of the party members and the general public are the same, all along with the school's research and teaching business indicators go. Branch no development planning, some planning, but also with the passage of time and behind. Branch contact mass work is not enough, cannot form a strong political core and fighting fortress, the lack of cohesion and the guiding role of the students; Individual party members cannot be strict demands on themselves, ignoring the overall development of the branch, it is difficult to play an exemplary role.

\section{The Contents and Form of the Branch Work is Lack of Innovation}

From the results of the questionnaire and the interview, the existing problems of the content and form of the Party branch of the basic level teachers in Colleges and Universities [6], mainly is simple to carry out a number of commemorative activities by means of the party's day, national day, other is to follow the central situation go, requirements for organizational learning, is in accordance with the requirements of the arrange, above is not required 
to check and branch secretary nor the implementation of inspection and enthusiasm. Organization of democratic life will be mainly in accordance with the instructions of the superiors. In addition, the party membership dues are month handed in on time, only about $20 \%$ of the amount of return branch as the activity funds, these funds may also set aside a part to take care of family difficulties, or is the teacher is sick, so leave the party activity funds stretched, branch written activities there is always pressure, this also makes the party activities in the form of innovation is difficult, in a certain extent restricted the activities of the branch.

\section{The Competent Authorities Should Pay Enough Attention to the Extent}

From the survey, there are few schools can give each branch to find space to carry out activities, let alone to have a fixed party members of the studio. Usually with the help of the teachers' office, student party room, or college reference room, some schools even in a corner of the room opened up a place for some journals even branch space. This situation seriously affected the image of the Party branch, the impact of Party members and teachers' confidence and the sense of belonging to the organization, the organization of activities in the form of a small amount of the inevitable.

\section{E. Incentive Mechanism is Not Perfect}

There are a lot of college party members and teachers' performance is the same as the ordinary people, some party members are not as good as the ordinary people, and even some of the teachers in the masses is the reverse role, a serious impact on the image of Party members. The reason for this is because there is no incentive mechanism, as long as the task of scientific research is a good comrade.

The template is used to format your paper and style the text. All margins, column widths, line spaces, and text fonts are prescribed; please do not alter them. You may note peculiarities. For example, the head margin in this template measures proportionately more than is customary. This measurement and others are deliberate, using specifications that anticipate your paper as one part of the entire proceedings, and not as an independent document. Please do not revise any of the current designations.

To sum up, the main problems existing in the Party branch of college teachers, in the final analysis is neglected. To sum up, the main problems existing in the Party branch of college teachers, in the final analysis is neglected. On the one hand is the leaders in policy and system to make the standard. On the other hand, Party members and teachers cannot in accordance with the standards of Party members' strict demands on themselves, confusion in the general public, did not play its proper model to take the lead role.

\section{HOW TO PLAY THE ROLE OF THE INCENTIVE \\ MECHANISM IN THE CONSTRUCTION OF THE PARTY BRANCHES OF TEACHERS IN COLLEGES AND UNIVERSITIES}

Because of the high knowledge level of university teachers in their respective subject areas have a strong professional knowledge, the information has a keen sense of information, information acquisition ability, easy to accept new things [5], thinking active, good information literacy, so in the process of building the Party branch should be fully integrated into the role of incentive mechanisms, integration of these advantages.

\section{A. Promote the Enthusiasm of the Work, Improve the Cohesion of the Organization}

In order to improve the enthusiasm and consciousness of Party members' work, we must analyze the working motivation and the need of Party members' teachers. Just to participate in the work of teachers, especially in the big cities of the "young teachers" who are more concerned about the level of income, the work environment and the vitality of the environment, that is, the survival needs of the ERG theory, the relationship between needs and growth needs. So managers should be for teachers as soon as possible to adapt to teaching post service, to provide more opportunities to develop, improve the working enthusiasm, equipped with the old teacher as a guide, in branch activities held invite young people advice, recommend them to participate in academic activities, in the branch of the organization in a variety of activities, play the enthusiasm, salon young members of the Communist Party, to carry out, through these activities make it as soon as possible into the working environment, melt into the branch, establish the correct work motivation, strengthen Party member's identity have been recognized degree, play branch of agglomeration effects at the core, improve the teachers of the branch organization of belonging.

\section{B. Strengthen Goal Setting Orientation, Improve Job Satisfaction}

Work satisfaction is the employee's cognition, emotion and behavior tendency, the development is dynamic [7], and the management should learn to solve the problem in the development, improve the management effect of goal orientation. The goal setting of college teachers can be divided into three aspects: individual effort, performance and job satisfaction, and the related factors, such as target characteristics and personal ability and characteristics, organizational support and other factors, figure 1 shows the relationship between the number of people and the role of the original [8]. 


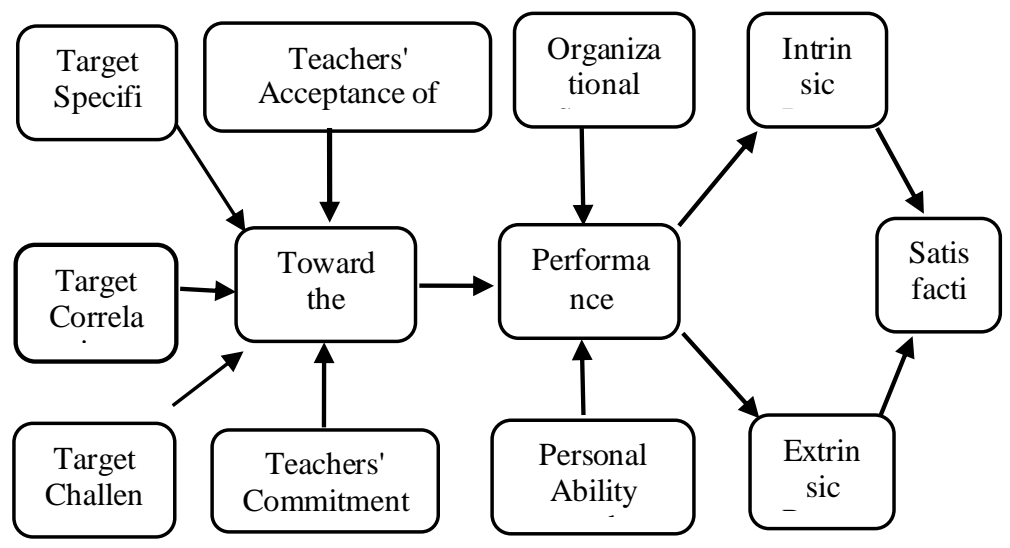

Figure 1. Basic Steps in the Application of the Goal Setting Theory

When the teacher got a specific job target and thought that it has some challenge, but with its own efforts to complete, will accept the goal and make a commitment, this has the incentive of the target will make it work force; The ability to achieve goals or objectives will be affected by the ability of the individual and the impact of organizational support. When the performance of the time, employees should be rewarded, these rewards can be divided into two parts, the internal and external incentives such as personal academic value, personal social value is recognized, external rewards can be praised, obtain certificates, etc., teachers can get timely encouragement or reward will strengthen their job satisfaction.

Pay attention to the combination of material motivation and spiritual motivation [9]. There are a lot of ways of spiritual motivation, such as team building, service oriented Party branch construction, the use of modern WeChat platform, network sharing resources platform will be a variety of different forms of branch teachers in different ways, can play the role of spiritual motivation.

The Party branch of the basic level teachers in Colleges and universities can be combined with the characteristics of the professional development, will be built on the branch of the professional, built on the post, respect for the development of the teacher's personality, set up with different goals. Fully mobilize the enthusiasm of professional teachers and students, the construction of features of the grass-roots party branches, such as the creation of service-oriented Party branch, the model of Party branches, learning party branches, and the development of the party and the country to carry out a variety of activities, so that the party building work more colorful.

\section{Enhance the Degree of Attention, to Create a Harmonious and Fair Work Environment for Party Members}

Incentive theory shows that a group of people who need to belong to the organization, the easier to form a harmonious working atmosphere and easy to carry out all kinds of work. The more members you have, the more you will be able to play a better role in the development of the work. Therefore, managers should attach great importance to the party members and teachers, teachers should pay more attention to the teaching and scientific research work, so that teachers can have a difficult time. Achievements need to meet the needs of teaching and scientific research evaluation mechanism, so that party members and teachers can be subject to the school assessment indicators, in the role of the branch. Branch secretary in carrying out work should pay attention to the results of the activities as long as the control, it should allow the party members' innovation, positive behavior is strengthened, negative behavior, so as to create a harmonious, fair competition environment for Party members.

\section{Improve the Incentive Mechanism, Make the Development of the Branch}

The basic orientation of the development of the Party branch of University teachers: The political core of the direction of school running [10]. Target management should take this as the core of the step, sustainable development, improve the incentive mechanism to achieve a plan, implementation, supervision, assessment, feedback and other basic links. The plan is part of the actual process of goal setting, requirements for participation in the higher the better; Target implementation requires a certain system as a guarantee, there are certain organization (suggested here play the role of grass-roots party branches) and regulatory indicators and guarantee the goal realization, and application of pre designed evaluation index of target realization truthfully examination, using the right way will timely feedback the inspection results, so the cycle, will be able to ensure realization of branch development orientation of the target.

\section{CONCLUSIONS}

There are many problems in the development of the Party branch construction of the university teachers, and the path design based on the teacher's personal, branch construction, system security can provide a valuable reference for the whole Party construction innovation.

1. Through the innovation of the content and form of the work, improve the enthusiasm of teachers, improve the cohesion of the party organization;

2. Strengthen goal setting orientation, improve the teachers' satisfaction to work;

3. Management to improve the party building work of the degree of attention, for Party members to create a harmonious and fair work environment; 
4. Improve the incentive mechanism, to make the development of the branch.

\section{ACKNOWLEDGMENTS}

2015 National Social Science Fund Project : Research on the Innovation of the Party Building Pattern in the Perspective of the Rule of Law, No: 15BDJ021.

2015 Dalian University Party Branch Innovation Project: The Study of the Interaction between the Party Branch Construction and the Ideological and Political Education in the Marx College

\section{REFERENCES}

[1] Liu Yingxia.Human Resource Management[M]. Beijing:People

[7] Wang Yan, Guo Zhida. Behavior in Organizations[M].Beijing: Jingji and Management Press.2014（3）,P81-82.

[8] Liu Yingxia, Xi Jizong.The Study of Branch Party Committee Construction For College Professors as the Goal.Journal Dalian University, 2015 (10) ,P129.

[9] Chen Chunhua, Yang Zhong, Cao Zhoutao.Behavior in
University Press,China, 2015, P24.

[2] Liu Yingxia. China Economist [J]. 2007 (5) , P131.

[3] Locke,E.A.,Latham,G.P.A theory of goal setting and task performance.Englewood Cliffs,NJ:Prentice-Hall.1990.

[4] Jerald Greenberg, Robert A.Baron.Behavior in Organizations [M].Beijing:People University Press, China. 2015, P240- 245.

[5] Zeng Haiyan. Research on the Long-Term Mechanism of the Advanced Construction of the Party Branch of the University Teachers[J], Journal of Lanzhou Institute of Education.2015 (1) ,P36.

[6] Cao Yan, Zhang Jian, Xing Aijia. Research and Practice of the Life and Innovation of the Party Branch of the Basic Level of the University[J]. Management \& Technology of SME (The Edition of Second Half).2014 ( 5 ) .P264 Organizations[M].Beijing:China Machine Press,2010, P85,P90-.91. [10] Liu Daoping, Liu Qiuling, Fan Zhengfei,etal. The Scientific Research on the Construction of the Party Branches of the University Teachers[J]. Party's History and Construction in Shanghai.2013. 